\title{
Value chain analysis of weaving industry
}

\author{
Analisis rantai nilai industri tenun
}

\author{
Diah Ayu Rini \& Sri Rahayu Budiani \\ Department of Geography and Environmental Sciences, Faculty of Geography, Universitas Gadjah Mada \\ Address: Sekip Utara Jalan Kaliurang, Bulaksumur, Yogyakarta 55281 \\ E-mail: diahayurini10@gmail.com \& srbudiani@yahoo.com \\ Phone: 085643090267
}

\begin{abstract}
Value chain analysis is used to discover the distribution of the supply of raw materials and the marketing of industrial products. The research study focus was located in Gamplong Tourism Village, Sleman regency, Daerah Istimewa Yogyakarta. The aims of this research were to 1) map the value chain of the weaving industry in Gamplong Tourism Village; 2) to identify existing obstacles to the weaving industry in Gamplong Tourism Village and 3) to determine appropriate strategies to minimise the obstacles in the weaving industry in Gamplong Tourism Village. The analysis used in this research was a descriptive analysis. The respondents in this study were 47 industry actors, the distributors of raw materials and marketing individuals. Data collection was conducted using a census and in-depth interviews with the weaving industry actors. This was snowballed to the distributor. Based on the results of the research, the value chain of the weaving industrial products as a whole consists of six actors, namely raw material suppliers, raw material distributors, weaving industry actors, distributors, retail traders, and consumers. The household industry value chain differs from the small and medium industry value chain. Some of the obstacles to the Gamplong weaving industry are the length of the value chain, no labour regeneration, and less tourism village development. Therefore, strategies to reduce these obstacles include cutting down the value chains, managing human resources, and increasing the promotion strategies used.
\end{abstract}

Keywords: value chain; weaving industry; Gamplong Tourism Village

\begin{abstract}
Abstrak
Analisis rantai nilai digunakan untuk melihat persebaran pemasokan bahan baku dan pemasaran hasil produksi industri. Penelitian ini dilakukan di Desa Wisata Gamplong, Kabupaten Sleman, Daerah Istimewa Yogyakarta. Penelitian ini bertujuan untuk memetakan rantai nilai Industri tenun di Desa Wisata Gamplong dan mengenali faktor penghambat yang ada dalam industri tenun di Desa Wisata Gamplong. Studi ini juga menentukan strategi yang tepat untuk meminimalisir hambatan dalam industri tenun di Desa Wisata Gamplong. Analisis yang digunakan dalam penelitian ini adalah analisis deskriptif. Responden dalam penelitian ini adalah pelaku/ pemilik industri tenun dengan jumlah populasi sebanyak 47 pelaku/pemilik industri, distributor bahan baku dan pemasaran. Pengambilan data dilakukan secara sensus dengan wawancara mendalam kepada pelaku industri tenun dan pengambilan data secara snowball dengan wawancara terstruktur kepada distributor. Dari penelitian ini dapat ditemukan bahwa rantai nilai produk industri tenun secara keseluruhan terdiri dari enam aktor, yaitu pemasok bahan baku, distributor bahan baku, pelaku industri tenun, distributor, pedagang pengecer, dan konsumen. Rantai nilai industri rumah tangga berbeda dengan rantai nilai industri kecil dan menengah. Beberapa hambatan industri tenun Gamplong adalah panjangnya rantai nilai, tidak ada regenerasi tenaga kerja, dan pengembangan desa wisata kurang optimal. Strategi untuk mengurangi hambatan tersebut adalah pemotongan rantai nilai, pengelolaan sumberdaya manusia, dan peningkatan strategi promosi.
\end{abstract}

Kata kunci: rantai nilai; industri tenun; Desa Wisata Gamplong

\section{Introduction}

Economic development is a process that causes per capita income to increase in the long-term (Sukirno 2003). The industrial sector has an important role in economic development, marked by changes in the economic structure of the community, especially the home industry. The existence of a home industry will be able to increase household income by encouraging the fulfilment of community needs through production so as to reduce dependence on outside goods and to expand 
employment (Hasanah \& Widowati 2011).

The household industry requires a strategy to continue and survive. A strategy is a continuous and simultaneous action that is done consistently, and that is carried out based on the point of view of what is expected in the future (Aulia \& Ikhwana 2012). The reality is that many household industries experience a collapse because they cannot compete with other large industries, and because the welfare of home industry owners is decreasing.

The weaving industry is one of the more famous industries in Moyudan District. This industry is one of the industries that has stood against all the obstacles that have occurred in Gamplong Tourism Village, Moyudan District, Sleman. The weaving industry in this area has used a Non-Machinery Weaving Tool (NMWT) or a traditional loom since the 1950s, producing carrying weaving, napkins, calico, and stagen.

The development of technology has had a major influence on the type of weaving that has developed because the innovations of the craftsmen will be increasingly developed. According to the Chairperson of the Gamplong Weaving Industry Association, weaving industry productivity has decreased because weaving production is less creative and finally, some weaving industry subsectors cannot keep up with the era's progression and eventually turn to other industries. According to the Chairperson of the Gamplong Weaving Industry Association, other problems that are faced by producers are the higher price of raw materials and the difficulty in obtaining them. Most of the labourers who produce the weaving products are elderly. The industry also has decreased marketing, has a lack of innovation and development from the craftsmen, and there is a lack of knowledge in terms of technological developments. These problems are triggered by several things such as the higher price of raw materials, labour, and marketing. There needs to be an in-depth study on the value chain activities of the weaving industry.

Value chain analysis (value chain) will be able to assist in the creation of strategic decision-making when facing increasingly fierce business competition (Friska 2010). The value chain describes how to see a company as a chain of activities that converts inputs (raw materials) into outputs that are valuable to customers (finished goods). Value chain analysis helps in determining the position of the company so then it is able to determine the right strategy to deal with the competition and to resolve any barriers that exist in the primary industry activities, such as logistic procurements in operations, the procurement of outside logistics, sales and marketing and services (Porter 1998).

Based on the description above, this study has the following objectives: 1) to map the value chain of the weaving industry in Gamplong Tourism Village, 2) to find out the obstacles in the weaving industry in Gamplong Tourism Village, and 3) to determine the right strategy to minimise constraints in the weaving industry in Gamplong Tourism Village.

\section{Research Method}

The respondents in this study were weaving industry players and raw material distributors, as well as marketing distributors. The population of weaving industry players was made up of 47 industry players. The data collection method used was a census for industry players and the snowball method for the raw material distributors and marketing. The method of analysis used in this research was a quantitative descriptive analysis using frequency tables and cross tabs. The value chain analysis was used to determine the activity pattern of raw material supply related to marketing, and to find out the barriers to each industrial activity in order to formulate strategies to minimise said obstacles.

\section{Result and Discussion}

\section{Gamplong Weaving Industry Characteristics}

Gamplong Tourism Village is one of the hamlets in Moyudan District, Sleman Regency, Yogyakarta Special Region. This tourism village is famous for weaving NMWT (Non-Machine Weaving Tools). This weaving industry has existed since the 1950s. Figure 1 shows that the number of Gamplong weaving industries each year has generally experienced a decline since 2008, and there are only a 
handful of weaving sub-industries that are still active. Handicrafts product have undergone several changes in order to adjust to the times. In the past, the types of handicrafts produced were stagen and lendang. Nowadays, production has developed, resulting in placemats, napkins, bags and other crafts.

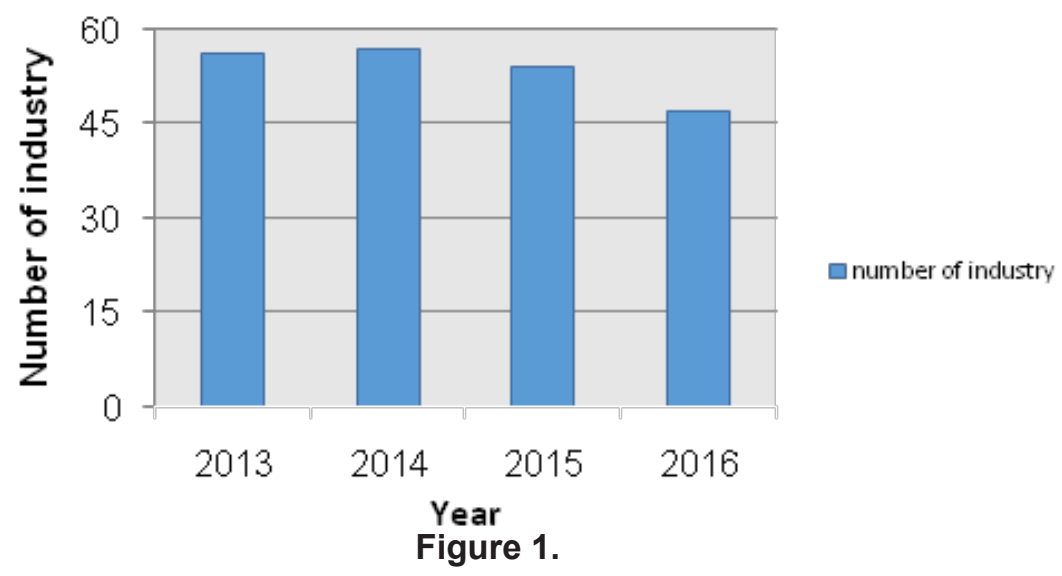

The number of Gamplong weaving sub-industries 2013 to 2016

Based on the number of workers, the industries in Gamplong Tourism Village can be divided into three sectors, as in Table 1. Most of the industries in Gamplong Tourism Village are home industries with woven products such as stagens and napkins, while the small and medium industries related to weaving products produce more diverse goods such as stagens, napkins, placemats, mats, bags etc. In addition, the numbers of workers in the small and medium industries produce more goods compared to the home industry, so the productivity of the small and medium industries is greater and hence it can compete better in the market place.

Table 1.

Type of industry based on the number of workers in Gamplong Tourism Village

\begin{tabular}{|c|c|c|}
\hline Type of industry & Total & Percentage (\%) \\
\hline Home industry & 30 & 63.8 \\
\hline Small industry & 12 & 25.5 \\
\hline Middle industry & 5 & 10.6 \\
\hline Total & 47 & 100.00 \\
\hline
\end{tabular}

\section{Industry Value Chain}

Value chain is a cost management analysis tool in strategic decision making in facing the increasingly fierce business competition (Silitonga 2010). The value chain describes how to view a company as a chain of activities that converts inputs (raw materials) into outputs that are valuable to customers (finished goods). Value chain analysis tries to understand how a business creates value for customers by examining the contribution of different activities in the business to those values (Pearce \& Robinson 2008). This value chain comes from activities carried out, ranging from raw materials to the finished product for consumers, including after sales services.

The value chain framework divides activities within companies into two general categories, that are main activities and supporting activities (Kusumawati 2013). The main activities are activities related to the physical product creation such as sales, and distribution, and after sales service. The value chain structure is divided into five elements, i.e. the end markets, supporting businesses and environments, vertical relationships, horizontal relationships, supporting markets. Value chain dynamics consist of upgrading, setting the value chain, the power used by companies in inter-company relations, cooperation and competition between companies, transfer of information and learning outcomes between companies (Campbell 2008). 


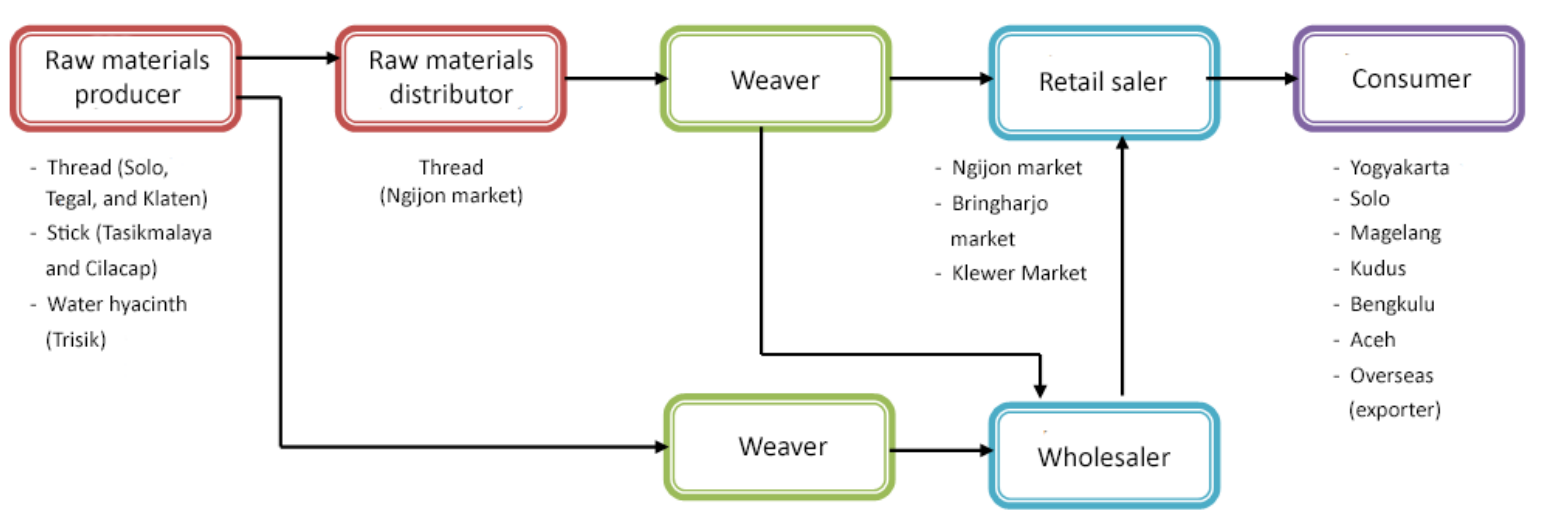

Figure 2.

Home industry value chain of Gamplong weaving

Raw materials are the material used when making products where the material is completely visible on the finished products (or the largest part of the goods). The production process requires labour, raw materials, capital in all of its forms and expertise or skills. Production is every effort that creates or enlarges the utility or value of the goods (Rosyidi 2004). Production is a part of productivity, where production is an activity or industrial activity related to output. Productivity is an industrial activity that deals with the efficient use of resources and labour, which plays an important role in the value of productivity. Increased productivity and efficiency are the main sources of growth when realising sustainable development. Otherwise, high and sustainable growth is also an important element in maintaining the sustainability of long-term productivity improvements. The amount of labour and capital will affect output growth if the quality of the two resources increases. Marketing or distribution is an economic activity that functions to bring or deliver goods and services from the producers to the consumers (Farid \& Subekti 2012).

The value chain is a systematic approach used when analysing competitiveness and development. Value chains are also used to test production and the supporting processes that will contribute to the competitive advantage of an industry. The competitive advantage of an industry can be seen from the activities carried out by the industries, ranging from planning, production, marketing, shipping and including support for their production (Porter 1985). These industrial activities are carried out in order to evaluate the contributions provided by the internal processes used to provide customer value. Competitive advantage will be developed based on innovations and economic vitality, which is a direct result of inter-industrial competition (Christanto 2011).

The value chain structure in each of the Gamplong Tourism Village's weaving industries is different, both in the activities of supplying the raw materials to the marketing of the products. This difference is caused by the origin of the raw materials, the amount of raw material used, and the marketing process of each industry where it is influenced by individuals and institutions. The value chain of the Gamplong weaving industry is divided into two; the value chain of the home industry and the small and medium enterprise value chain.

The value chain of the home industry shows that processing raw materials to be able to turn them into products for the consumers involves going through four to five chains as shown in Figure 2. In the industrial value chain, the producers of raw materials market their products to distributors or directly market them to weaving craftsmen. Most of the home industry actors get the raw materials from a small retailer in Ngijon Market. This is due to the lack of capital ownership and the small amount of the labour who work in the industry, which consists of less than four people from the direct family. As a result, they are not capable to produce stagens or napkins in large quantities. The products of the weaving industry are marketed through two intermediaries, i.e. wholesalers and retailers in Ngijon Market and Bringharjo Market. 


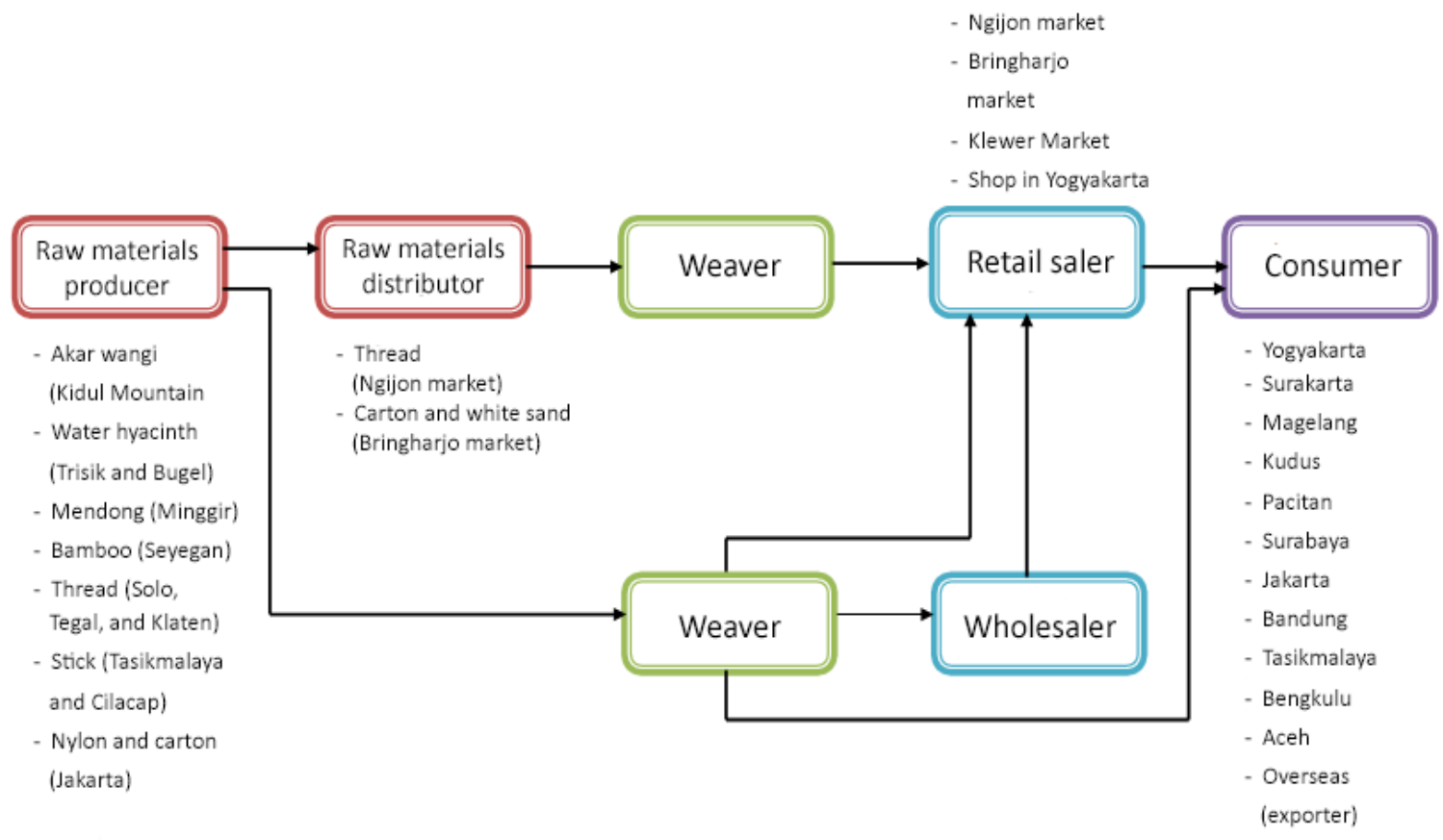

Figure 3.

Small medium enterprise value chain of Gamplong weaving industry

The value chain of the small medium enterprise as in Figure 3 shows that processing raw materials to the consumers must pass through 4 to 2 chains, or hands. Raw material producers conduct marketing through two intermediaries, such as through distributors or directly to the craftsmen. Most of the small medium enterprises get woven raw materials directly from the raw material producers. The marketing of the production of small medium industries is done through wholesaler, retail traders and directly to consumers.

Table 2.

The chain actor and their role

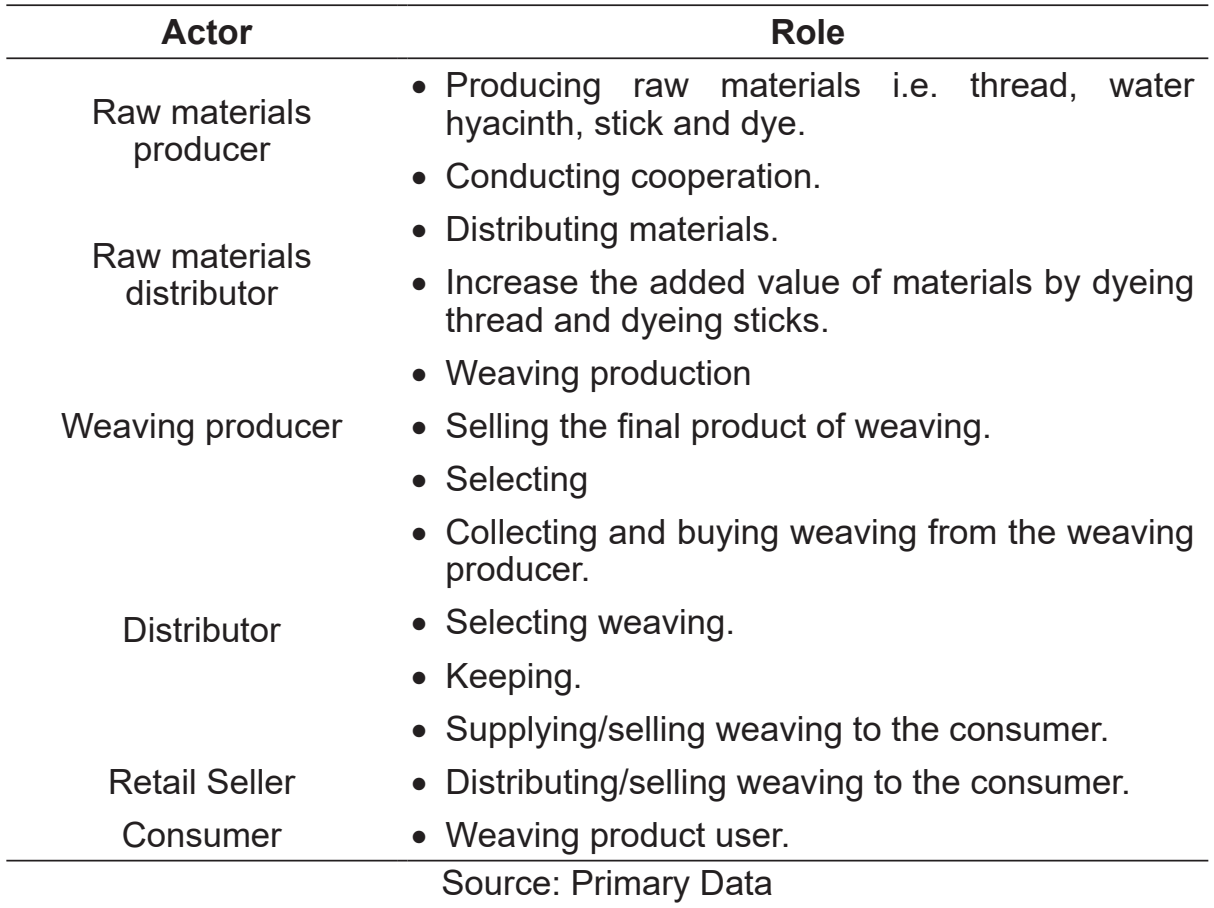


Table 3.

The number of industries based on the method of providing raw materials

\begin{tabular}{ccc}
\hline Way of providing & $\begin{array}{c}\text { Number of } \\
\text { home industry }\end{array}$ & $\begin{array}{c}\text { Number of small } \\
\text { medium enterprise }\end{array}$ \\
\hline Raw material producer & 6 & 13 \\
Raw material distributor & 24 & 4 \\
Total & $\mathbf{3 0}$ & $\mathbf{1 7}$ \\
\hline \multicolumn{3}{c}{ Source: Primary Data }
\end{tabular}

Direct marketing to the customers will provide a better profit for both the industry and the consumers because both of them can negotiate separately and the benefits obtained is greater (Kotler \& Andreasen 1995). Direct marketing to consumers is done at the request of the consumer. In other words, the consumer orders the handicraft in accordance with their wishes, both in relation to the quantity, shape and price desired.

The weaving industry of Gamplong Tourism Village has several types of industrial value chain, both home industries and small medium enterprises. The value chain flow starts from the producers of raw materials, weaving producers, distributors, retailers, and consumers. Table 2 shows the role of each actor in the chain in relation to carrying out the activities, from the producers of raw materials through to the consumers of the Gamplong Weaving Industry.

Based on Figure 4, the location of raw materials comes from several outside production areas, i.e. directly to the first producer. The collection of the raw materials through the first raw material producer is carried out by several industry players who are members of the association. The association facilitates industry players in obtaining services, skills and information between companies, increases the benefits between companies, increases industry access to various markets, and reduces the market risk (Champbell 2008). There are several industries that supply raw materials through distributors as shown in Table 3.

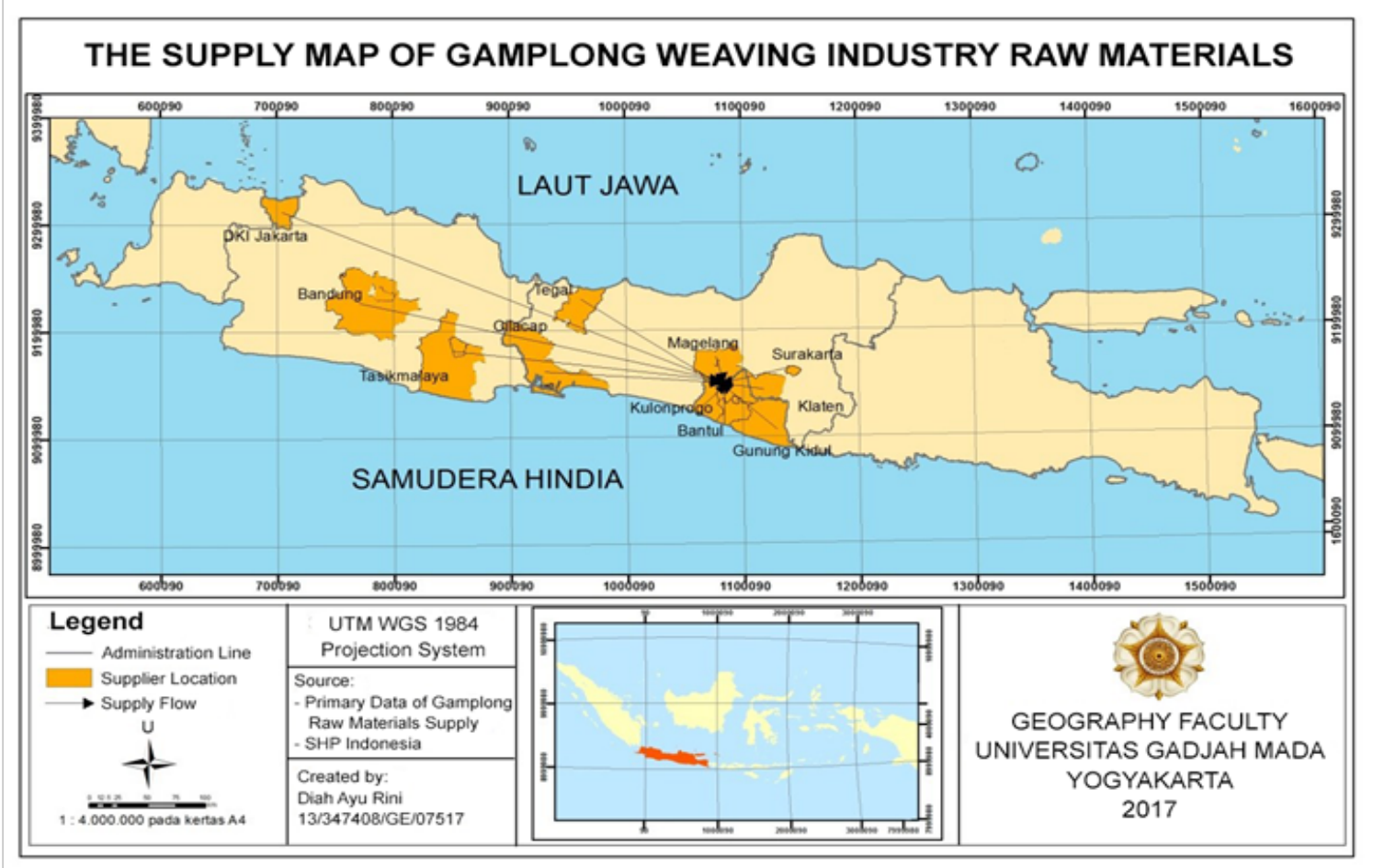

Figure 4.

The supply map of Gamplong weaving industry's raw materials 
The cooperation between value chain actors has a positive impact on both parties, such as in raw material supply and marketing activities. The marketing area of Gamplong weaving industry is quite broad, reaching an international scale through exporters. The marketing location of the Gamplong weaving industry is dominant in Java, as in the Marketing Location Map (Figure 5). The existence of such cooperation helps industry players to increase the profits of the company. This is a strategy determined by the industry players in relation of the marketing distribution channels for their industrial production goods. In order to distribute goods and services from producers to consumers, the industry must choose the distribution channel that is to be used, because errors in the selection of distribution channels can hamper and disrupt the effort involved in distributing the goods or services (Lubis 2004).

The price offered by each value chain actor varies based on the transportation costs used, as shown in Table 4. Based on the table, it can be seen that the price of each woven product varies and is increased in terms of the selling price every time changes market sector. This causes the price received by the consumers to be higher. Therefore, the longer the value chain, the higher the price offered. The added value of goods can also increase due to changes or additions to the marketed goods.

\section{Industrial Barriers and Strategies}

The causes of failure when developing an industry are due to a lack of experience, low communication skills, non-strategic location and high competitiveness (Fristia \& Navastara 2014). Gamplong Tourism Village's weaving industry has experienced a decline in the number of industries active annually. This is caused by several things, ranging from the supply of raw materials, production and marketing. In general, the shortcoming of the Gamplong weaving industry is the low level of productivity, financial management, and marketing.

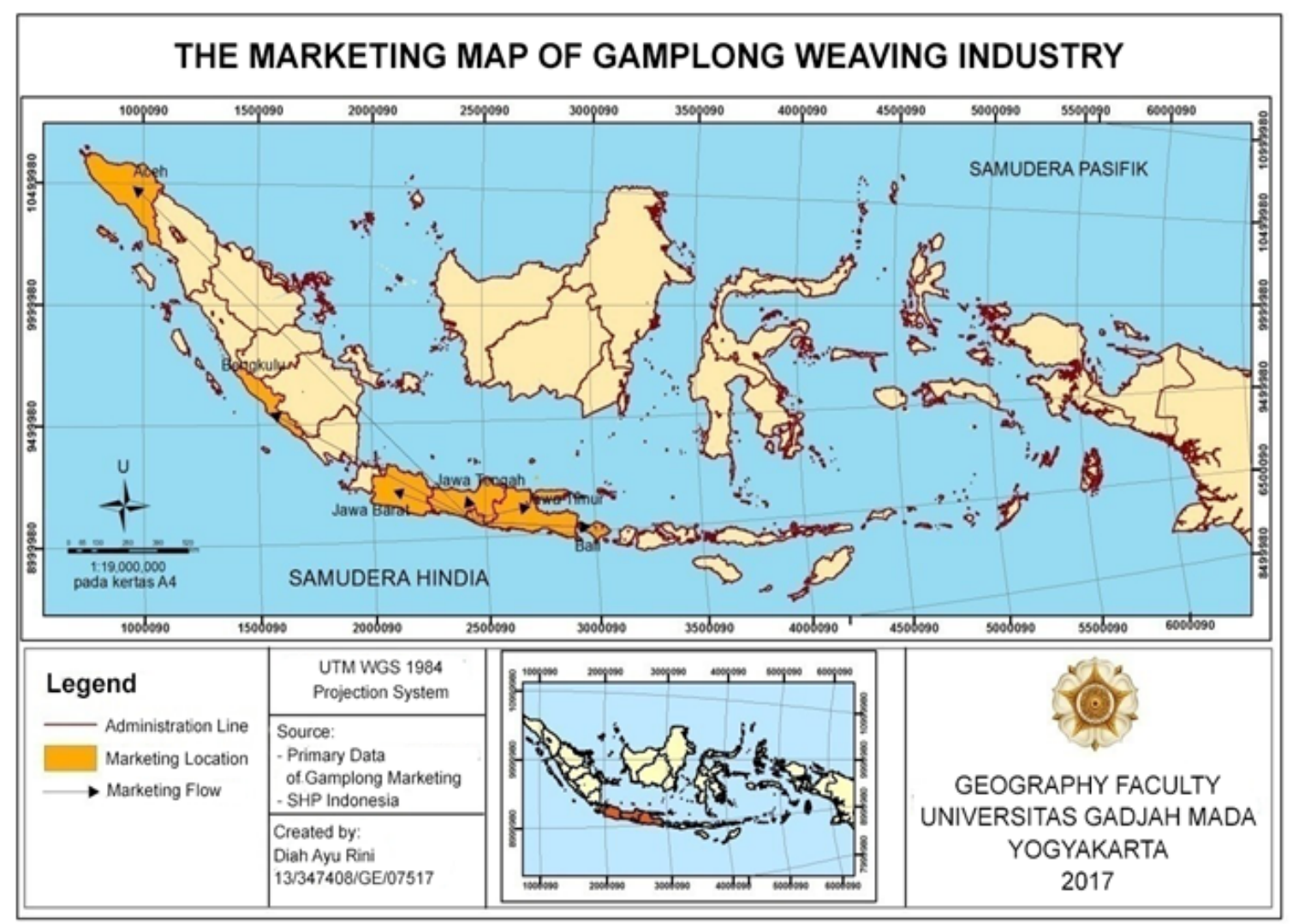

Figure 5.

The national scale marketing map of Gamplong weaving industry 
The low level of productivity is caused by the elderly workers and the old traditional weaving looms that are still used (Non-Machine Weaving Tools) as shown in Figure 6. Every worker is able to produce 3-4 stagens per day, while the mechanised machinery weaving industry can produce 10 pieces of stagens per day. In addition, the productivity of the elderly workers is declining simultaneously due to the number of workers. The Non-Machinery Weaving Tool has had a positive impact in terms of its ability to attracting visitors or tourists to visit tourist villages and to buy Gamplong woven products. Aside from that, the use of Non-Machinery Weaving Tools is a way to preserve the native culture while the use of Non-Machinery Weaving Tools has existed since the 1950s.

Table 4.

Weaving product price based on value chain

\begin{tabular}{cccc}
\hline Product & Weaver $\rightarrow$ Wholesaler & $\begin{array}{c}\text { Wholesaler } \rightarrow \text { Retail } \\
\text { seller }\end{array}$ & Retail seller $\rightarrow$ Consumer \\
\hline Stagen & Rp 15.000,00-Rp 16.000,00 & Rp 16.000,00-Rp 18.000,00 & Rp 19.000,00-Rp 20.000,00 \\
Napkin & Rp 1.800,00-Rp 2.000,00 & Rp 2.300,00-Rp 2.700,00 & $\operatorname{Rp~2.500,00-Rp~3.000,00~}$ \\
Placemats & $\operatorname{Rp~2.500,00-Rp~2.750,00~}$ & Rp 2.750,00-Rp 2.900,00 & $\operatorname{Rp~2.900,00-Rp~3.250,00~}$ \\
\hline
\end{tabular}

Source: Primary Data

Another problem is the absence of labour regeneration, where the majority of young workers prefer to work in factories rather than in the weaving industry. Therefore, the number of skilled workers in the weaving industry is decreasing, which will have a negative impact on the sustainability of the industry. There is a need to train young workers and to increase the production for the development of the weaving industry.

Capital is also a problem in the weaving industry. Each Gamplong weaving industry has different primary capital. The capital owned by the industrial actor in this sector consists of money and NonMachine Weaving Tools. The difference in capital used by each entrepreneur will have a different influence on the level of income, production capability, market orientation and industrial continuity, so then the lack of money capital greatly limits the space for activities aimed at increasing income (Soraya 2011). Another problem that arises because of the available capital or profits from sales is meeting the worker's daily needs. This is due to the increase of living costs or vice versa, the use of daily living costs for industry capital fulfilment.

Strategy is a continuous action based on the perspective of what is expected in the future (Aulia \& Ikhwana 2012). The strategy is formulated based on the strengths and weaknesses of the weaving industry. Based on the research results, the advantages of the weaving industry make the manufacture taking place in Gamplong Village a source of tourism. The use of Non-Machine Weaving Tools is able to preserve the native culture, as well as the diversity of weaving products. This can be a driving factor in attracting the arrival of tourists or consumers to the weaving industry actors, which can increase the marketing of weaving products in this area.

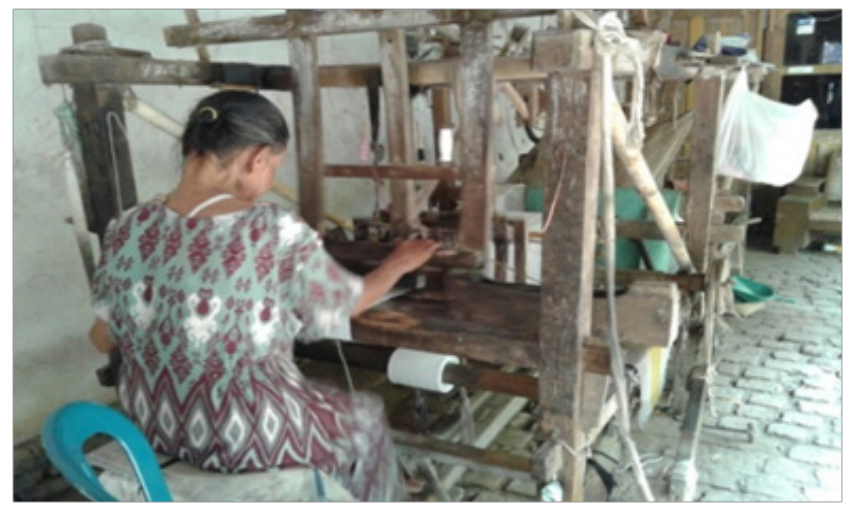

Figure 6.

Elderly worker of Gamplong weaving industry 
According to Gitosudarmo (1994), financial planning will help the industry owners to manage their finances so then the financial condition of the industry will be better, because the better the budget plan, the better the industry finances, since things have been calculated and planned. Human resource management is an important strategy for increasing productivity by conducting weaving skills training and learning about the prospects of marketing in the weaving industry related to young workers. Young workers will be more interested in the weaving industry because the weaving industry is considered to be promising. Based on the field research, the obstacles and strategies that can be experienced and developed by the weaving industry actors can be seen in Table 5 .

Table 5.

The strategic formulation of Gamplong weaving industry based on each industry activities' obstacles

\begin{tabular}{|c|c|c|}
\hline $\begin{array}{l}\text { Industrial } \\
\text { activities }\end{array}$ & Industrial Obstacle & Industrial strategies \\
\hline Raw materials & $\begin{array}{l}\text { - Most of the industry rely upon } \\
\text { distributors to provide the raw } \\
\text { materials. } \\
\text { - Raising price of raw materials and } \\
\text { limited raw material availability. } \\
\text { - Low financial management. }\end{array}$ & $\begin{array}{l}\text { - The management of raw materials } \\
\text { supply using cutting value chain by } \\
\text { taking the raw materials directly to } \\
\text { the first producer. } \\
\text { - Financial planning. }\end{array}$ \\
\hline Production & $\begin{array}{l}\text { - Low productivity caused by low } \\
\text { year of success, elderly work } \\
\text { force, traditional looms. } \\
\text { - Low innovation. }\end{array}$ & $\begin{array}{l}\text { - Human resources management. } \\
\text { - Improving relations with consumers } \\
\text { and institutions and the improvement } \\
\text { of weaving product type. }\end{array}$ \\
\hline Marketing & $\begin{array}{l}\text { - Low marketing prospects. } \\
\text { - Low technology usage. } \\
\text { - Most of the industry sell the final } \\
\text { product through distributors and } \\
\text { retailers. }\end{array}$ & $\begin{array}{l}\text { - Product strategy by creating product } \\
\text { logos and improving the weaving } \\
\text { product type. } \\
\text { - Price strategy; monitoring market } \\
\text { situation. } \\
\text { - Promotion strategy improved by } \\
\text { using the internet. } \\
\text { - Distribution strategy by direct } \\
\text { marketing to customers and } \\
\text { developing the tourism village. }\end{array}$ \\
\hline
\end{tabular}

Source: Primary Data

\section{Conclusion}

Based on the results of the study, it can be concluded that the value chain of the weaving industry product as a whole consists of six actors; raw material suppliers, raw material distributors, weaving industry players, distributors, retailers and consumers. Based on the results of the study, the constraints in the weaving industry are divided into three based on the industrial activities. Most of the constraints on the raw material supply activities are to do with taking raw materials through distributors, increasing the raw material prices, the limited availability of raw materials, and low financial management. In addition, the constraints on production activities are the low productivity due to the low number of years of success, the elderly workforce, the use of traditional looms and low level of innovation. The constraints on the marketing activities are the low level of marketing prospects, low level of technology use, and most of the industries market their resulting products through distributors and retailers.

Strategic formulation is based on the constraints in every industrial activity. The strategy for raw material supply activities is focused on cutting the value chain by taking the raw materials from the first producer and financial planning. The strategy for production activities is the management of human resources and improving the relationship between the consumers and the related institutions, 
while also increasing the variety of weaving products. The strategy that can be formulated for use in relation to the marketing activities is product strategy. It works by making product logos and increasing the type of weaving products available, creating pricing strategies by reading the market conditions, creating promotion strategies enhanced by internet use, and making distribution strategies by directly marketing to consumers and developing tourism villages.

\section{References}

Aulia D \& Ikhwana A (2012) Perencanaan strategi pengembangan usaha kain tenun sutra dengan pendekatan metode balanced scorecard (Studi kasus di Pabrik Sutra Tiga Putra). Jurnal Kalibrasi Sekolah Tinggi Teknologi Garut 10 (1):1-12.

Campbell R (2008) Kerangka Kerja Rantai Nilai. Majalah Frontier Edisi Juli 2008:3-4. Jakarta. USAID, Magister Manajemen FE Universitas Indonesia - SENADA.

Christanto J (2009) Membangun Daya Saing Daerah melalui Penciptaan Kompetensi Inti Daerah. Yogyakarta: Penerbit Deepublish.

Djamhari C (2006) Faktor-faktor yang mempengaruhi perkembangan Sentra UKM menjadi klaster dinamis. Jurnal Infokop 29 (24):83-92.

Farid M \& Subekti NA (2012) Tinjauan terhadap produksi, konsumsi, distribusi dan dinamika harga cabe di Indonesia. Buletin Ilmiah Litbang Perdagangan 6 (2):211-234.

Fitriady MY (2011) Analisis peluang pasar untuk mengembangkan produk olahan jamur merang di Jawa Timur. Jurnal Ekonomi dan Bisnis 10 (1):19-24.

Friska S (2010) Value chain analysis (Analisis rantai nilai) untuk keunggulan kompetitif melalui keunggulan biaya. Jurnal Ekonom 13 (1):36-44.

Fristia VF \& Navastara AM (2014) Faktor penyebab belum berkembangnya industri kecil batik Desa Kenongo Kecamatan Tulangan-Sidoarjo. Jurnal Teknik Pomits 3 (2). ISSN: 2337-3539.

Gitosudarmo I (1994) Manajemen Pemasaran. Yogyakarta: BPFE.

Hasanah EU \& Widowati P (2011) Analisis produktivitas tenaga kerja pada industri rumah tangga krecek di Kelurahan Segoroyoso. Jurnal Bisnis dan Ekonomi 2 (2).

Kotler P \& Andreasen AR (1995) Strategi Pemasaran untuk Organisasi Nirlaba. Yogyakarta: UGM Press.

Kusumawati A (2013) Rantai nilai (Value chain) agribisnis labu di Kecamatan Getasan Kabupaten Semarang. Thesis, Faculty of Economy and Business, Universitas Diponegoro.

Lubis AN (2004) Peranan saluran distribusi dalam pemasaran produk dan jasa. Jurnal Universitas Sumatera Utara.

Pearce \& Robinson (2008) Manajemen Strategis, Formulasi, Implementasi dan Pengendalian. Jakarta: Penerbit Salemba Empat.

Porter ME (1985) Competitive Advantage. New York: Free Press.

Porter ME (1998) On Competition. Boston: Harvard Business School Publishing.

Rosyidi S (2004) Pengantar Teori Ekonomi Pendekatan kepada Teori Ekonomi Mikro \& Makro. Surabaya: Rajawali Pers.

Silitonga S (2010) Value chain analysis (Analisis rantai nilai) untuk keunggulan kompetitif melalui keunggulan biaya. Jurnal Ekonom 13 (1):36-44.

Soraya P (2011) Studi industri kerajinan serat agel di Desa Salamrejo Kecamatan Sentolo Kabupaten Kulon Progo. Thesis, Faculty of Social Science and Economy, Universitas Negeri Yogyakarta.

Sukirno S (2003) Pengantar Teori Mikro Ekonomi. Jakarta: Salemba Empat. 